\title{
Communication
}

Rumana Azad, K.L. Wasantha Kumara, Gamini Senanayake, R.A.A.K. Ranawaka,D.K.N.G. Pushpakumara, Sudarshanee Geekiyanage*

\section{Flower morphological diversity of cinnamon (Cinnamomum verum Presl) in Matara District, Sri Lanka}

https://doi.org/10.1515/opag-2018-0025

received January 5, 2018; accepted June 7, 2018

\begin{abstract}
The cinnamon flowers exhibit protogynous dichogamy with 2 flower types "Type A" and "Type B" which first flowers during morning and evening respectively. This floral cycle causes a temporal barrier to the maintenance of elite breeding material and for hybridization with desired parents. Determination of variation in flower and inflorescence morphology can shed light on functional diversity in "Type A" and "Type B" flowers. In order to study these variations, a survey of cultivated cinnamon lands and wild habitats was conducted in fifteen locations in the Matara district. Peduncle length (PDL), flower length (FL), flower width (FW), and floral tube length (FTL) varied among cinnamon accessions collected. The variation in tepal shape was distinct: the two whorls of tepals of a single flower exhibited two shapes. The current investigation of differences in inflorescence, floral morphology and floral abnormalities of Cinnamomum verum provides information about their diversity, and recommends molecular analysis to further determine the genetic basis of two flower types in progynous dichogamy.
\end{abstract}

Keywords: Cinnamomum verum, diversity of floral morphology, floral abnormalities, inflorescence, protogynous dicogamy

\footnotetext{
*Corresponding author: Sudarshanee Geekiyanage, Department of Agricultural Biology, Faculty of Agriculture, University of Ruhuna, Mapalana, Kamburupitiya, Sri Lanka,

E-mail: sudarshanee@agbio.ruh.ac.lk

Rumana Azad, Board of Study in Agriculture, Faculty of Graduate Studies, University of Ruhuna, Matara, Sri Lanka

K.L. Wasantha Kumara, Gamini Senanayake, Department of Agricultural Biology, Faculty of Agriculture, University of Ruhuna, Mapalana, Kamburupitiya, Sri Lanka

R.A.A.K. Ranawaka, Department of Export Agriculture,1095, Sirimavo Bandaranayake Mawatha, Peradeniya, Sri Lanka D.K.N.G Pushpakumara, Department of Crop Science, Faculty of Agriculture, University of Peradeniya, Peradeniya, Sri Lanka
}

\section{Introduction}

The cultivated cinnamon (Cinnamomum verum) belongs to family Lauraceae. The genus Cinnamomum consists of about 250 species found in Asia and Australia (Jayaprakasha et al. 2003). Kumarathilake et al. (2010) studied the eco geographical distribution and the extinction risk level of wild relatives of cultivated cinnamon. Sri Lankan cinnamon contributes to $70 \%$ of the world's true cinnamon bark production (Abeysinghe et al. 2009). A favourable environmental conditions for cinnamon are found in wet zone of Sri Lanka. The optimum temperature for cinnamon cultivation lies between $25^{\circ} \mathrm{C}-32^{\circ} \mathrm{C}$ (Department of Export Agriculture 2013). Wide morphological variation of cultivated cinnamon is detected in farmer fields in Sri Lanka due to cross pollination. Protogynous dichogamy in cinnamon leads to cross pollination. According to Kumari et al. (2008), there are two types of plants named Type A, in which stigma becomes receptive during morning, and Type B with receptive stigma in the afternoon. The flower opening cycle is completed within a span of 12 hours as anthers become dehiscent in the evening in "type A" and in the morning on the next day in "type B". Overlapping periods in "Type A" and "Type B" flowers result in cross pollination. Kumari et al. (2008) determined that the majority of cultivars tested belong to "type B'.

Variation due to possible cross pollination, among mother plants, their progeny and other plants in more than 50 year old population was determined through age-independent morphological characters of leaf shape, leaf base and leaf apex by Azad et al. (2015). None of the progenies was $100 \%$ similar to mother plants. New phenotypes for leaf shape and leaf base were reported in progeny indicating the contribution of cross pollination to allele richness leading to morphological variation in cinnamon germplasm. 
Although Gamble (1967), Hooker (1883), Joseph (1981), Kubitzky and Kurz (1984), Mohankumar et al. (1985), Ravindran et al. (2004) and Purseglove (1969) also studied some aspects of floral biology of cinnamon, the information is still incomplete. Environmental factors may affect the floral cycle of cinnamon. Possible effect of day length on flowering time manipulation has not been studied yet, as indicated by Sedgley (1985) about the floral cycle of Avocado of family Lauraceae. As reported by Purseglove (1969), flowers of Cinnamomum verum were found in axillary and terminal panicles at the end of twigs. Its peduncle is creamy white and 5-7 cm long. Individual flowers are very small, of about $3 \mathrm{~mm}$ in diameter, with a foetid smell. A small, ovate and hairy bract subtends from the flower. There are six campanulate and pubescent sepals. There are nine stamens in three whorls with glands at the base. The filaments of stamen are hairy and anthers are four-celled opening through four small valves. There are three staminodes. The ovary is superior and one-celled. The main reports on cinnamon floral morphology by Purseglove (1969) and Dassanayake et al. (1995) indicated differences.

Flowering in cinnamon is reported to have started by November and continues until the early part of March (Joseph 1981; Kubitzki and Kurz 1984; Mohanakumar et al. 1985). The fruits are ripen from May to June. However, according to our observation in southern Sri Lanka, off season flowering occurs in March and April, and occasionally in August and September.

The development of breeding material through hybridization of superior genotypes is hampered by the lack of information on floral cycle and flower morphology, because progynous dichogamy causes a temporal separation between androecium and gynacium. Despite the presence of some unpublished information on the large size of Type A flowers, flower morphological markers for flower "Types A and B" of floral cycle have not been determined yet. The study of floral morphology is important for genotypes in commercial cultivation and in the wild in order to be maintained through self pollination and to be crossed respectively. Therefore, the present study was conducted to determine the morphological variation of flower and inflorescence of Cinnamomum verum from cultivated lands and natural habitats in Matara district, Sri Lanka, where commercial cultivation is common. The present study would provide basis for molecular characterization for flower diversity to mine useful genes in protogynous dichogamy in the future work.

\section{Methods}

A field survey was conducted in 15 locations of Matara, Sri Lanka in February, 2016 (Figure 1). Fifteen cinnamon accessions with representative inflorescence and flower morphologies from cultivated lands and wild habitats were considered for this study. The floral abnormalities were also recorded. Information on inflorescence nature/ pattern, floral colour, size and structure were observed in 5 flowers from each accession based on information of previous work (Dassanayake et al. 1995; Purseglove 1969).

Four quantitative morphological characters of peduncle length (PDL), flower length (FL), flower width (FW), and floral tube length (FTL) were measured from fifteen accessions. The average value of five readings was taken for a character from each accession for the analysis. Clustering of fifteen accessions into four groups was carried out based on above four quantitative morphological characters following Ward's hierarchical algorithm of squared Euclidean distances using IBM SPSS Statistics 20.0 software (version 20), IBM, USA. The four

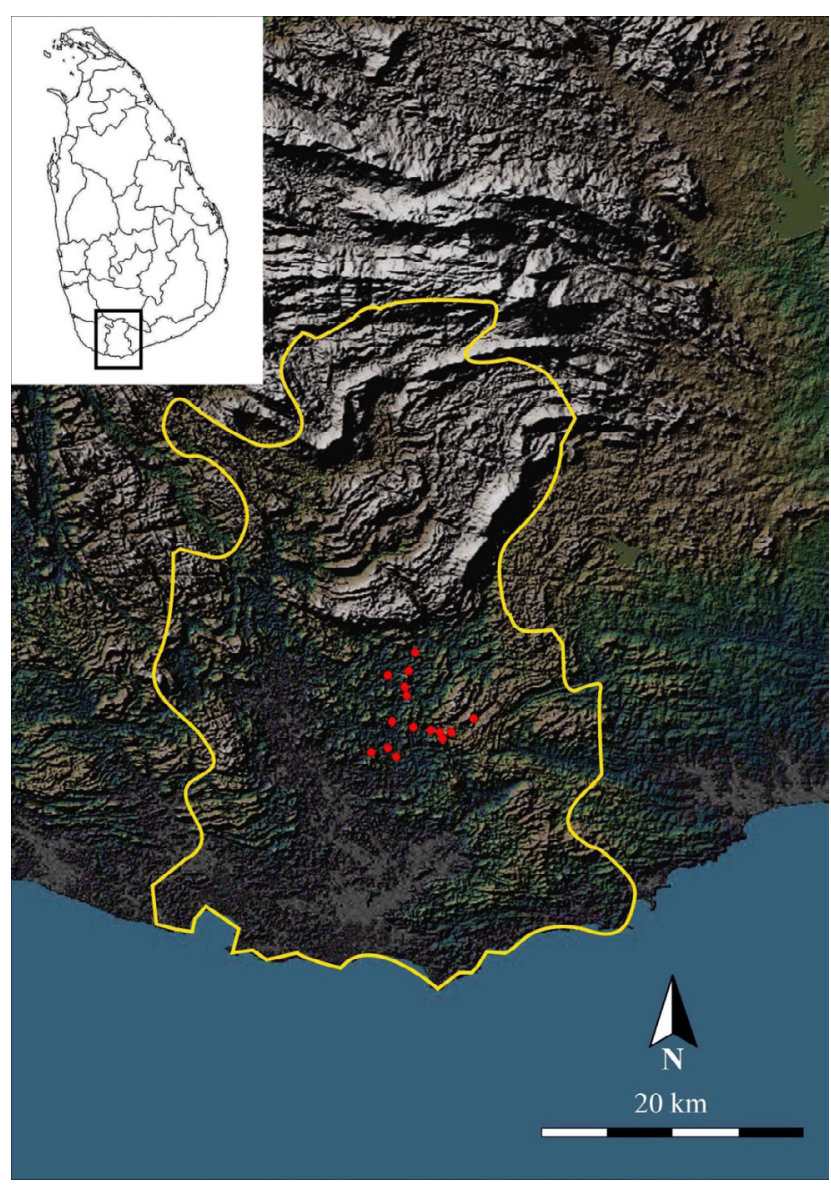

Figure 1: Collection sites in Matara district of Sri Lanaka; collection sites are indicated by red circles 
quantitative characters from each cluster were analyzed by one-way ANOVA and differences within cluster and between clusters were determined through Tukey's post hoc comparisons at $p<0.05$ level for significant differences.

Ethical approval: The conducted research is not related to either human or animal use.

\section{Results and Discussion}

The four quantitative morphological characters of PDL, FL, FW, and FTL varied among fifteen accessions. The cluster analysis using Ward's method based on above morphological characters classified the fifteen cinnamon accessions in to four clusters at rescaled distance of 5 (Figure 2). The variation in morphology was depicted through cluster analysis: mean scores of clusters for each character were analyzed and differences between clusters were determined by Tukey's post-hoc test (Table 1). The PDL of the accessions varied among clusters. The highest $(137.66 \mathrm{~mm})$ and the lowest $(79.60 \mathrm{~mm})$ mean values were reported from cluster 4 and cluster 2 respectively, which were significantly different at $p<0.05$.

Flower length varied: the highest was an average of $10.25 \mathrm{~mm}$ (from cluster 1) and the lowest was an average of $8.17 \mathrm{~mm}$ (from cluster 3). The average FL differences, scaled by clusters were significant at $p<0.05$. In the Tukey post-hoc testing, pair wise comparisons were significant between cluster 1 with cluster 2 and cluster 3. Furthermore,

Table 1: Values (Mean \pm S.E.M) of quantitative characters according to clusters with results of $F$ tests and Tukey post-hoc analysis

\begin{tabular}{|c|c|c|c|c|c|c|}
\hline & Cluster 1 & Cluster 2 & Cluster 3 & Cluster 4 & & \\
\hline Morphological traits & $M \pm S . E . M$ & $M \pm S . E . M$ & $M \pm S . E . M$ & $M \pm S . E . M$ & $F$ & $p$ \\
\hline PDL & $91.90 \pm 3.100$ & $79.60 \pm 1.756$ & $113.33 \pm 4.410$ & $137.66 \pm 3.482$ & $75.22^{\text {bcdef }}$ & 0.000 \\
\hline $\mathrm{FL}$ & $10.25 \pm 0.250$ & $8.50 \pm 0.158$ & $8.17 \pm 0.333$ & $9.80 \pm 0.339$ & $9.71^{\text {abef }}$ & 0.002 \\
\hline $\mathrm{FW}$ & $6.25 \pm 0.250$ & $6.29 \pm 0.560$ & $7.48 \pm 0.775$ & $7.08 \pm 0.471$ & 0.94 & 0.455 \\
\hline FTL & $6.25 \pm 0.250$ & $3.85 \pm 0.302$ & $3.33 \pm 0.083$ & $4.45 \pm 0.572$ & $4.95^{\mathrm{ab}}$ & 0.021 \\
\hline
\end{tabular}

$N=15$ (Cluster 1, $n=2$; Cluster 2, $n=5$; Cluster 3, $n=3$; Cluster 4, $n=5$ ); F tests $\mathrm{df}=3,11$; significant mean difference between the clusters on Tukey post-hoc contrast at $p<0.05$; Tukey pairs: $\mathrm{a}=$ cluster- 01 and cluster- $02, \mathrm{~b}=$ cluster- 01 and cluster-03, $\mathrm{c}=$ cluster-01 and cluster$04, \mathrm{~d}=$ cluster- 02 and cluster-03, $\mathrm{e}=$ cluster- 02 and cluster-04, $\mathrm{f}=$ cluster-03 and cluster-04; PDL = Peduncle length; FL = Flower length; FW $=$ Flower width; FTL = Floral tube length.

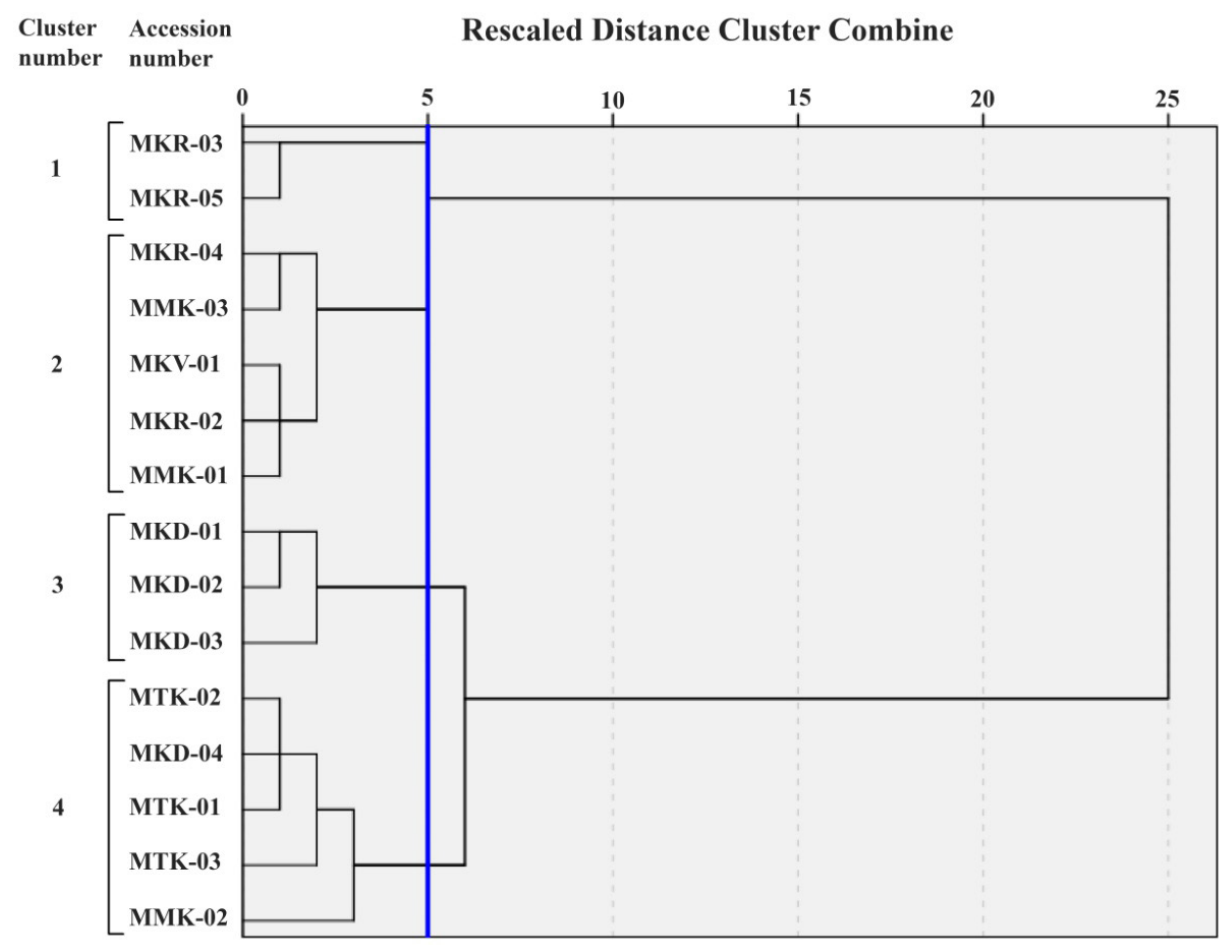

Figure 2: Cluster analysis of fifteen cinnamon accessions based on four morphological characters 
significant differences existed between clusters between 2 and 4, and also between cluster 3 and 4 .

The highest $(7.48 \mathrm{~mm})$ and the lowest $(6.25 \mathrm{~mm}) \mathrm{FWs}$ were recorded in cluster 3 and cluster 1 , respectively, although there were no significant differences between the clusters for FW at $p<0.05$. Floral tube length was the highest $(6.25 \mathrm{~mm})$ and the lowest $(3.33 \mathrm{~mm})$ in cluster 1 and cluster 3, respectively. There was a significant difference between the clusters in regards to FTL at $p<0.05$ : the FTLs of cluster 1 were different from those of cluster 2 and cluster 3.

Morphological variations of inflorescence and flower are summarized in Table 2. Further, six representing cinnamon accessions from the four clusters are given in Figure 3. All accessions produced axillary panicles (Table 2). The arrangement of panicles suggested that panicles are usually formed at the apex of the branchlets, as found in clusters 2, 3 and 4 (Figure 3; 3A and 5A). However, panicles can also be formed both from the axil and apex of the branchlets, which were found in cluster 1, 2 and 4 (Figure 3; 2A, 4A and 6A). The maximum PL of $13-17 \mathrm{~cm}$ was detected in cluster 4 and the minimum PL of $6.5-10 \mathrm{~cm}$ was found in cluster 2 . Three flower colours were observed in cinnamon accessions. A pale green flower colour was recorded in all clusters (Figure 3; $2 \mathrm{C}, 3 \mathrm{C}$ and $5 \mathrm{C}$ ). A pale yellowish green flower colour was found in cluster 2 and 3 (Figure 3, 6C), while a pale yellowish flower colour was observed only in cluster 4 (Figure 3, 4C). The maximum FL and maximum FW were recorded in cluster 4 and 3 respectively. All accessions showed six petals in two whorls. However, the shapes of the tepals were different among clusters. Lanceolate, ovate and oblong-lanceolate shapes were observed in cluster 2, 3 and 4 respectively (Figure 3; 1C, 5C and 4C). Interestingly, two tepal shapes in two whorls were also observed in all four clusters, where first whorl was lanceolate and second whorl was oblonglanceolate (Figure 3; 2C, 3C and 6C). An acute apex was found in tepals of all clusters (Figure 3; 2C, 3C and 6C) and an additional subacute apex was observed in cluster 2, 3 and 4 (Figure 3; 1C, 4C and 5C). All four clusters showed differences in inflorescence and flower morphological characters indicating diversity among the cinnamon accessions.

According to our observation, the standard floral characters comprises of six tepals in two whorls and fifteen stamens in three whorls; both whorl I and whorl III contain six stamens, while whorl II contains only three stamens. In the ovary, only one ovule is located. A style arises from the ovary. Three staminal glands are present in between stamen whorl II and the stigma (Figure 5B). Flower dimensions were not completely presented in previous reports, except for the report on the diameter of individual flowers as $3 \mathrm{~mm}$ by Purseglove (1969). Variations of flower dimensions are reported during the current study as FL measuring $7.5-11.0 \mathrm{~mm}$ (with average of $9.1 \pm 0.3 \mathrm{~mm}$ ), FW measuring $5.0-9.0 \mathrm{~mm}$ (with average of $6.79 \pm 0.3 \mathrm{~mm}$ ) and FTL measuring 3.0-6.5 mm (with average of $4.27 \pm 0.3 \mathrm{~mm}$ ).

The shape of cinnamon flower tepal was reported to be oblong-lanceolate (Ravindran et al. 2004). According to our study, ovate tepals were also found in cinnamon accessions from Matara district. Joseph (1981) reported the presence of six tepals arranged in two whorls, without an indication about the shape of the tepals, whereas we report here of two tepal shapes in two whorls in the same flower.

Two deviations of flower morphology from normal flower were observed and named as floral abnormality -1 and floral abnormality-2, which are described as follows:

Floral abnormality-1: The percentage of the abnormality is only $2.70 \%$ of all flowers of a single plant (accession) used for the study. The flowers with above abnormality were borne on a few axillary panicles at the apex of brachlets. The peduncle was $12-15 \mathrm{~cm}$ long with sub-branches. The flower was pale yellowish in colour. Flower length varied from 9-10 $\mathrm{mm}$ and width from 5.8-6.2 $\mathrm{mm}$. There were seven tepals in two whorls (as 4+3), which were lanceolate. The apex was acute and other floral parts were the same as a normal flower (Figure 4. 1A, 1B and1C).

Floral abnormality-2: The percentage of the abnormality is only $1.45 \%$ of all flowers of a single plant (accession) used for the study. Flowers were borne on axillary panicle with short axil and at the apex of branchlets. The peduncle was $10-13 \mathrm{~cm}$ long with subbranches. The flower was pale green. The FL varied form 7-8 $\mathrm{mm}$ and FW from 7.9-8.1 $\mathrm{mm}$. There were eight tepals in two whorls (as 4+4). The apex was lanceolate and acute. The stamen whorl I and whorl III contained 8 stamens each. The stamen whorl II had four stamens and four staminal glands. In the gynoecium, there were one style, one stigma, an ovary and one ovule (Figure 4. 2A, $2 \mathrm{~B}$ and $2 \mathrm{C}$ ).

The PDL of collected accessions ranged from 74.5$150.0 \mathrm{~mm}$ (with an average of $107.34 \pm 6.7 \mathrm{~mm}$ ) (Figure 6). The PDL reported from Matara district during this study was longer than that recorded in previous studies by Dassanayake et al. (1995) and Wuu-Kuang (2011).

There are variations observed in arrangement of inflorescence in terms of branchlets and single flower size, number of tepals and shape of the tepals as described above. Phenotypic plasticity or intraspecific genetic differentiation to local environment has previously been 
Table 2: Comparative inflorescence and floral morphology of representative cinnamon accessions derives from the four clusters

\begin{tabular}{|c|c|c|c|c|c|c|c|c|c|c|}
\hline $\begin{array}{l}\text { Cluster } \\
\text { number }\end{array}$ & $\begin{array}{l}\text { Accession } \\
\text { name }\end{array}$ & Inflorescence & $\begin{array}{l}\text { Density and } \\
\text { arrangement of } \\
\text { panicle }\end{array}$ & $\begin{array}{l}\text { Average } \\
\text { fpeduncle } \\
\text { length }(\mathrm{cm})\end{array}$ & $\begin{array}{l}\text { Flower } \\
\text { colour }\end{array}$ & $\begin{array}{l}\text { Average } \\
\text { flower } \\
\text { length } \\
(\mathrm{mm})\end{array}$ & $\begin{array}{l}\text { Average } \\
\text { flower } \\
\text { width } \\
(\mathrm{mm})\end{array}$ & $\begin{array}{l}\text { Tepal } \\
\text { number }\end{array}$ & Tepal shape & $\begin{array}{l}\text { Apex of } \\
\text { tepal }\end{array}$ \\
\hline 1 & MKR-03 & $\begin{array}{l}\text { Axillary } \\
\text { panicle }\end{array}$ & $\begin{array}{l}\text { Panicle } \\
\text { with long } \\
\text { branchlets, } \\
\text { panicles } \\
\text { formed both } \\
\text { from axil } \\
\text { and apex of } \\
\text { branchlets. }\end{array}$ & 8.88 & Pale green & 10.0 & 6.5 & $\begin{array}{l}6 \text { in } 2 \\
\text { whorls, } \\
3+3\end{array}$ & $\begin{array}{l}\text { First whorl } \\
\text { lanceolate } \\
\text { and second } \\
\text { whorl oblong- } \\
\text { lanceolate }\end{array}$ & Acute \\
\hline 1 & MKR-05 & & $\begin{array}{l}\text { Panicles } \\
\text { formed both } \\
\text { from axil } \\
\text { and apex of } \\
\text { branchlets. }\end{array}$ & 9.5 & Pale green & 10.5 & 6.0 & $\begin{array}{l}6 \text { in } 2 \\
\text { whorls, } \\
3+3\end{array}$ & $\begin{array}{l}\text { Oblong- } \\
\text { lanceolate }\end{array}$ & Acute \\
\hline 2 & MKV-01 & $\begin{array}{l}\text { Axillary } \\
\text { panicle }\end{array}$ & $\begin{array}{l}\text { Panicles } \\
\text { formed both } \\
\text { from axil } \\
\text { and apex of } \\
\text { branchlets, } \\
\text { panicles are } \\
\text { dense at } \\
\text { the apex of } \\
\text { branchlets. }\end{array}$ & 8.1 & $\begin{array}{l}\text { Pale } \\
\text { yellowish } \\
\text { green }\end{array}$ & 9.0 & 6.45 & $\begin{array}{l}6 \text { in } 2 \\
\text { whorls, } \\
3+3\end{array}$ & Lanceolate & Subacute \\
\hline 2 & MKR-04 & & $\begin{array}{l}\text { Panicle with } \\
\text { very short } \\
\text { branchlets, } \\
\text { panicles } \\
\text { formed only at } \\
\text { the apex of the } \\
\text { branchlets. }\end{array}$ & 7.45 & Pale green & 8.5 & 5.0 & $\begin{array}{l}6 \text { in } 2 \\
\text { whorls, } \\
3+3\end{array}$ & $\begin{array}{l}\text { First whorl } \\
\text { lanceolate } \\
\text { and second } \\
\text { whorl oblong- } \\
\text { lanceolate }\end{array}$ & Acute \\
\hline 2 & MMK-03 & & $\begin{array}{l}\text { Panicles } \\
\text { formed both } \\
\text { from axil } \\
\text { and apex of } \\
\text { branchlets, } \\
\text { panicles are } \\
\text { dense at } \\
\text { the apex of } \\
\text { branchlets. }\end{array}$ & 8.5 & Pale green & 8.5 & 5.0 & $\begin{array}{l}6 \text { in } 2 \\
\text { whorls, } \\
3+3\end{array}$ & $\begin{array}{l}\text { Oblong- } \\
\text { lanceolate }\end{array}$ & Subacute \\
\hline 2 & MKR-02 & & $\begin{array}{l}\text { Panicles } \\
\text { formed both } \\
\text { from axil } \\
\text { and apex of } \\
\text { branchlets, } \\
\text { panicles are } \\
\text { dense at } \\
\text { the apex of } \\
\text { branchlets. }\end{array}$ & 8.0 & $\begin{array}{l}\text { Pale } \\
\text { yellowish } \\
\text { green }\end{array}$ & 8.5 & 7.5 & $\begin{array}{l}6 \text { in } 2 \\
\text { whorls, } \\
3+3\end{array}$ & $\begin{array}{l}\text { Oblong- } \\
\text { lanceolate }\end{array}$ & Acute \\
\hline 2 & ММК-01 & & $\begin{array}{l}\text { Panicles } \\
\text { formed both } \\
\text { from axil } \\
\text { and apex of } \\
\text { branchlets. }\end{array}$ & 7.75 & Pale green & 8.0 & 7.5 & $\begin{array}{l}6 \text { in } 2 \\
\text { whorls, } \\
3+3\end{array}$ & $\begin{array}{l}\text { First whorl } \\
\text { lanceolate } \\
\text { and second } \\
\text { whorl oblong- } \\
\text { lanceolate }\end{array}$ & Subacute \\
\hline
\end{tabular}




\begin{tabular}{|c|c|c|c|c|c|c|c|c|c|c|}
\hline $\begin{array}{l}\text { Cluster } \\
\text { number }\end{array}$ & $\begin{array}{l}\text { Accession } \\
\text { name }\end{array}$ & Inflorescence & $\begin{array}{l}\text { Density and } \\
\text { arrangement of } \\
\text { panicle }\end{array}$ & $\begin{array}{l}\text { Average } \\
\text { fpeduncle } \\
\text { length }(\mathrm{cm})\end{array}$ & $\begin{array}{l}\text { Flower } \\
\text { colour }\end{array}$ & $\begin{array}{l}\text { Average } \\
\text { flower } \\
\text { length } \\
(\mathrm{mm})\end{array}$ & $\begin{array}{l}\text { Average } \\
\text { flower } \\
\text { width } \\
(\mathrm{mm})\end{array}$ & $\begin{array}{l}\text { Tepal } \\
\text { number }\end{array}$ & Tepal shape & $\begin{array}{l}\text { Apex of } \\
\text { tepal }\end{array}$ \\
\hline 3 & MKD-01 & $\begin{array}{l}\text { Axillary } \\
\text { panicle }\end{array}$ & $\begin{array}{l}\text { Panicles are } \\
\text { very dense at } \\
\text { the apex of } \\
\text { branchlets by } \\
\text { forming more } \\
\text { peduncles. }\end{array}$ & 10.5 & Pale green & 8.5 & 6.45 & $\begin{array}{l}6 \text { in } 2 \\
\text { whorls, } \\
3+3\end{array}$ & Ovate & Subacute \\
\hline 3 & MKD-02 & $\begin{array}{l}\text { Axillary } \\
\text { panicle }\end{array}$ & $\begin{array}{l}\text { Panicle } \\
\text { with short } \\
\text { branchlets, } \\
\text { panicles are } \\
\text { very dense by } \\
\text { forming more } \\
\text { sub-branches } \\
\text { of peduncle. }\end{array}$ & 12.0 & $\begin{array}{l}\text { Pale } \\
\text { yellowish } \\
\text { green }\end{array}$ & 8.5 & 7.0 & $\begin{array}{l}6 \text { in } 2 \\
\text { whorls, } \\
3+3\end{array}$ & $\begin{array}{l}\text { First whorl } \\
\text { lanceolate } \\
\text { and second } \\
\text { whorl oblong- } \\
\text { lanceolate }\end{array}$ & Acute \\
\hline 3 & MKD-03 & & $\begin{array}{l}\text { Panicles are } \\
\text { very dense at } \\
\text { the apex of } \\
\text { branchlets by } \\
\text { forming more } \\
\text { peduncles. }\end{array}$ & 11.5 & Pale green & 7.5 & 9.0 & $\begin{array}{l}6 \text { in } 2 \\
\text { whorls, } \\
3+3\end{array}$ & $\begin{array}{l}\text { First whorl } \\
\text { lanceolate } \\
\text { and second } \\
\text { whorl oblong- } \\
\text { lanceolate }\end{array}$ & Subacute \\
\hline 4 & MTK-03 & $\begin{array}{l}\text { Axillary } \\
\text { panicle }\end{array}$ & $\begin{array}{l}\text { Panicles } \\
\text { formed both } \\
\text { from axil } \\
\text { and apex of } \\
\text { branchlets. }\end{array}$ & 15.0 & Pale yellow & 10 & 8.4 & $\begin{array}{l}6 \text { in } 2 \\
\text { whorls, } \\
3+3\end{array}$ & $\begin{array}{l}\text { Oblong- } \\
\text { lanceolate }\end{array}$ & Subacute \\
\hline 4 & MTK-02 & & $\begin{array}{l}\text { Panicles } \\
\text { formed both } \\
\text { from axil } \\
\text { and apex of } \\
\text { branchlets, } \\
\text { panicles are } \\
\text { dense at } \\
\text { the apex of } \\
\text { branchlets. }\end{array}$ & 14.0 & Pale yellow & 9.0 & 7.5 & $\begin{array}{l}6 \text { in } 2 \\
\text { whorls, } \\
3+3\end{array}$ & $\begin{array}{l}\text { First whorl } \\
\text { lanceolate } \\
\text { and second } \\
\text { whorl oblong- } \\
\text { lanceolate }\end{array}$ & Subacute \\
\hline 4 & MKD-04 & & $\begin{array}{l}\text { Panicles are } \\
\text { very dense at } \\
\text { the apex of } \\
\text { branchlets by } \\
\text { forming more } \\
\text { peduncles. }\end{array}$ & 13.0 & Pale green & 9.5 & 7.5 & $\begin{array}{l}6 \text { in } 2 \\
\text { whorls, } \\
3+3\end{array}$ & $\begin{array}{l}\text { Oblong- } \\
\text { lanceolate }\end{array}$ & Subacute \\
\hline 4 & MTK-01 & & $\begin{array}{l}\text { Panicles } \\
\text { formed both } \\
\text { from axil } \\
\text { and apex of } \\
\text { branchlets. }\end{array}$ & 13.33 & Pale yellow & 9.5 & 6.0 & $\begin{array}{l}6 \text { in } 2 \\
\text { whorls, } \\
3+3\end{array}$ & $\begin{array}{l}\text { Oblong- } \\
\text { lanceolate }\end{array}$ & Acute \\
\hline 4 & MMK-02 & $\begin{array}{l}\text { Axillary } \\
\text { panicle }\end{array}$ & $\begin{array}{l}\text { Panicle with } \\
\text { very short } \\
\text { branchlets, } \\
\text { panicles } \\
\text { formed only at } \\
\text { the apex of the } \\
\text { branchlets. }\end{array}$ & 13.5 & Pale green & 11.0 & 6.0 & $\begin{array}{l}6 \text { in } 2 \\
\text { whorls, } \\
3+3\end{array}$ & $\begin{array}{l}\text { First whorl } \\
\text { lanceolate } \\
\text { and second } \\
\text { whorl oblong- } \\
\text { lanceolate }\end{array}$ & Acute \\
\hline
\end{tabular}



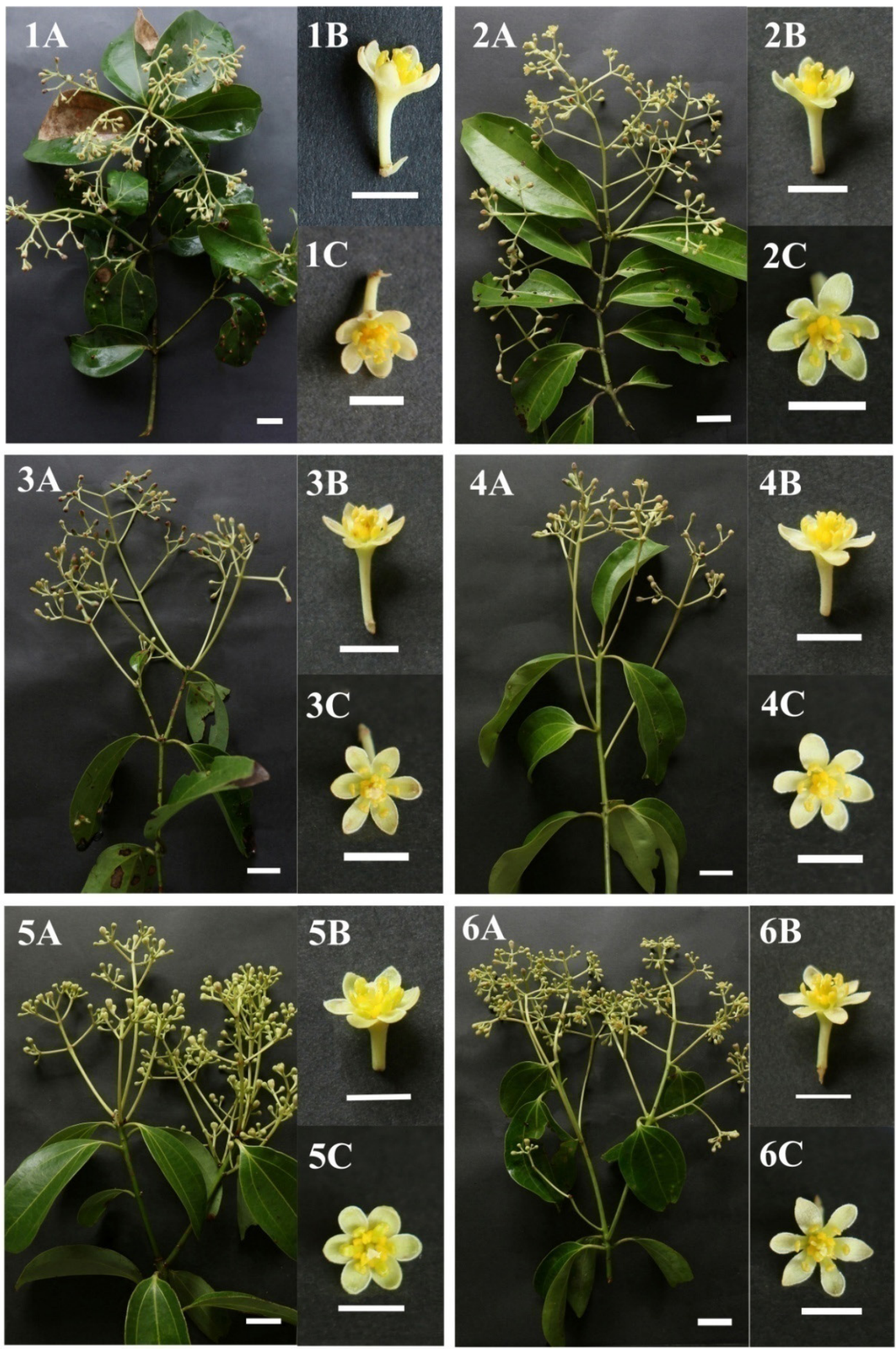

Figure 3: Inflorescence and single flower morphological variation in Cinnamomum verum. 1A, 1B \& 1C. accession no. MKV-01 from cluster no. 2; 2A, 2B \& 2C. accession no. MKR-03 from cluster no. 1; 3A, 3B \& 3C. accession no. MMK-02 from cluster no. 4; 4A, 4B \& 4C. accession no. MTK-03 from cluster no. 4; 5A, 5B \& 5C. accession no. MKD-01 from cluster no. 3; 6A, 6B \& 6C. accession no. MKD-02 from cluster no. 3. $(A=$ Inflorescence, $S$ cale $b a r=2 \mathrm{~cm} ; B=$ Longitudinal view of single flower, Scale bar $=5 \mathrm{~mm} ; C=$ Front view of single flower, $S c a l e$ bar $=5$ $\mathrm{mm})$ 

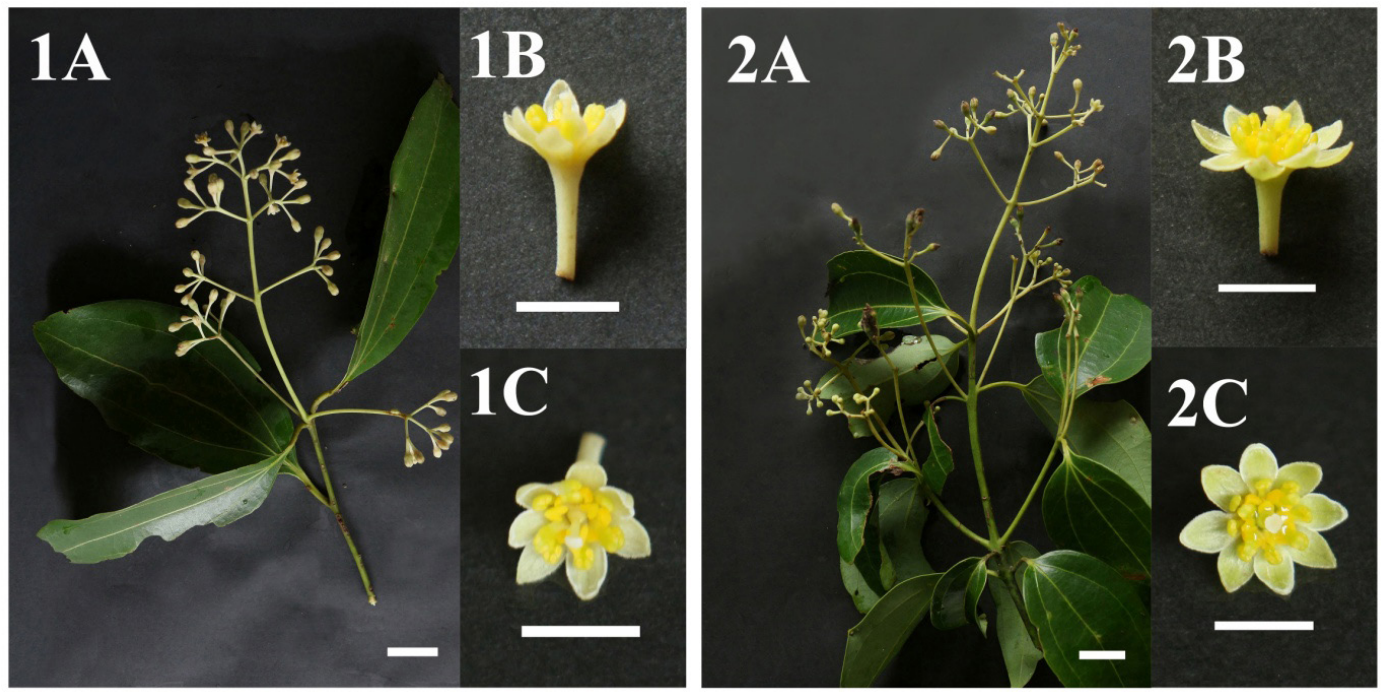

Figure 4: Floral abnormalities in Cinnamomum verum. $1 A$ \& 2A. Inflorescence, Scale bar $=2 \mathrm{~cm} ; 1 B \& 2 B$. Longitudinal view of flowers, Scale bar $=5 \mathrm{~mm}$ and $1 C \& 2 \mathrm{C}$. Front view of flowers, Scale bar $=5 \mathrm{~mm}$

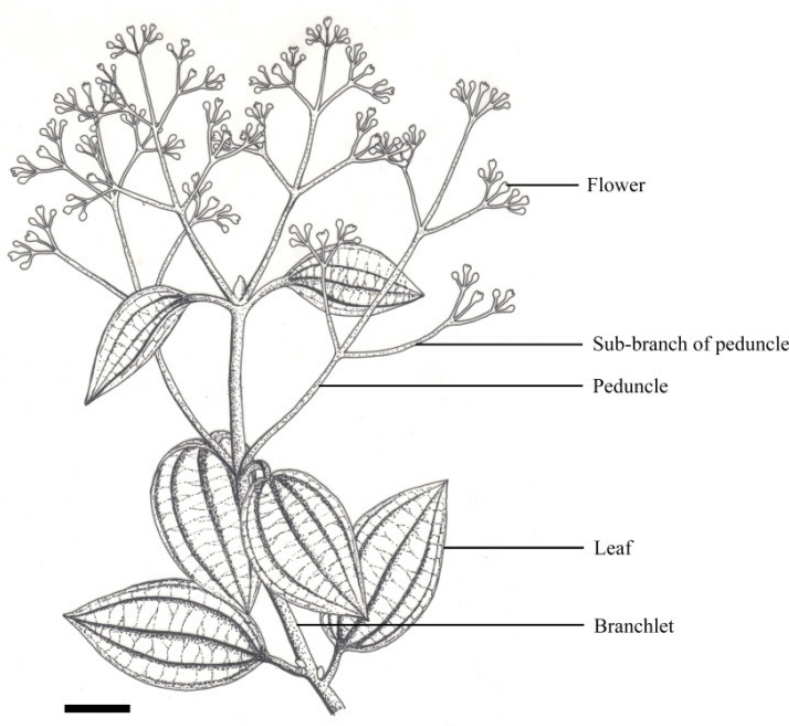

A

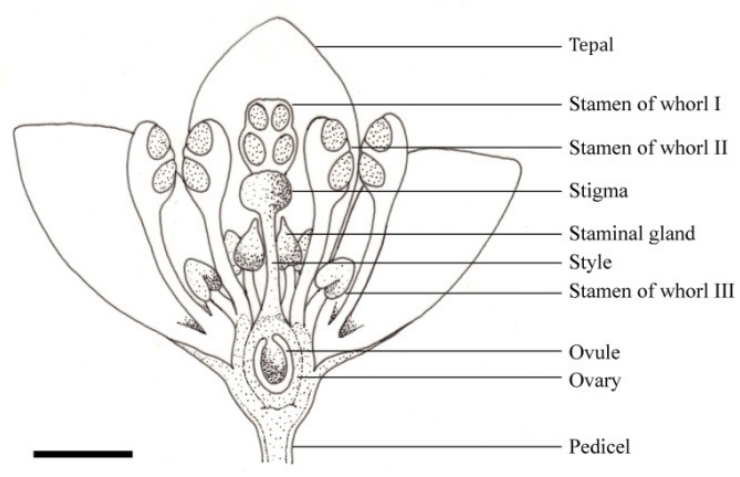

B

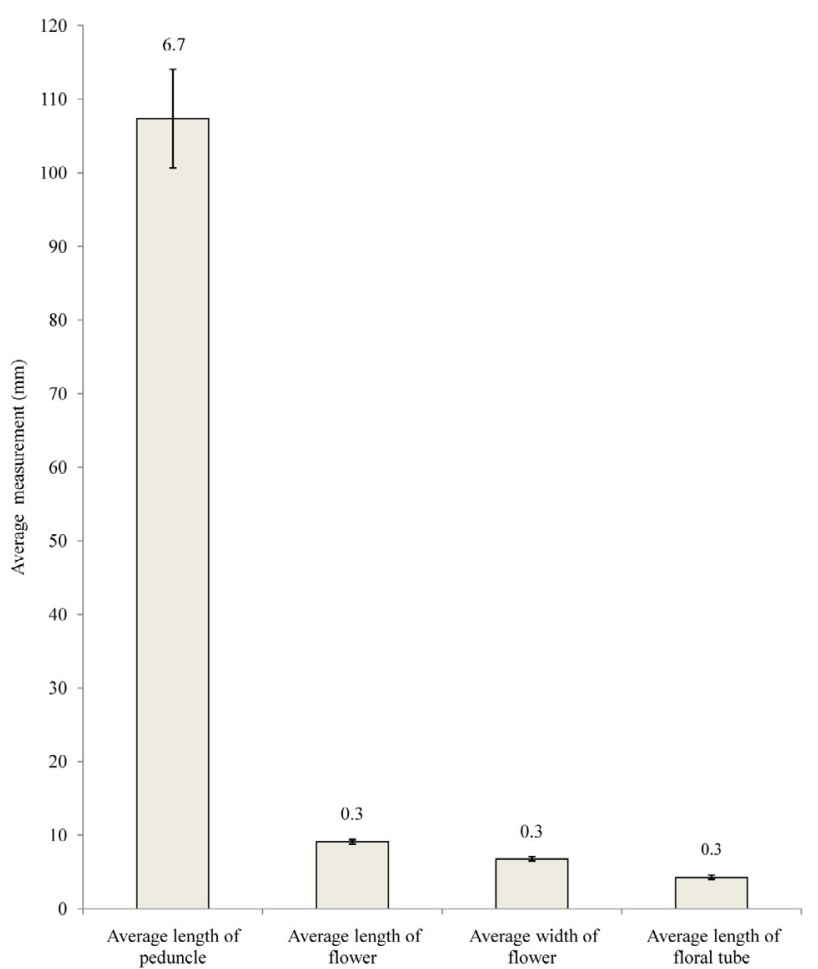

Figure 6: Average measurement of quantitative morphological characters of cinnamon accessions. Error bars represents the standard error of the mean
Figure 5: A. Diagram showing typical inflorescence of a single shoot of Cinnamomum verum. Scale bar $=2 \mathrm{~cm}$. B. Longitudinal section of a typical flower. Scale bar $=1 \mathrm{~mm}$ 
detected through morphological variation (Davis et al. 2005; Hendry et al. 2011; Nicotra et al.2010; Potvin and Tousignant 1996; Reed et al. 2011; Volis et al. 2015). The present study suggests the possibility that genetic differences among accessions may have led to morphological differences of 15 accessions from 15 locations in Matara district: microenvironmental factors may influence the gene expression for flower and inflorescence differences. In addition, testing the unpublished fact that "Type A" flowers are large in size is essential at molecular level in future work as significantly different flower lengths and widths were recorded during the study. Our study suggests that the allele diversity due to cross pollination, mutation or differential gene expression and differences in micro environmental conditions may lead to variation in floral morphology. An intensive study of floral morphology across Sri Lanka supported by a molecular analysis would reflect the full level of diversity within the species.

Acknowledgements: Authors wish to acknowledge the project Transforming University of Ruhuna into International Status (TURIS) 2013 grant (RU/TURIS/ $\mathrm{PhD} / 03$ ) for financial support of this study.

Conflict of interest: Authors state no conflict of interest.

\section{References}

Abeysinghe P.D., Wijesinghe K.G.G., Tachida H., Yoshda T., Thihagoda M, Molecular characterization of cinnamon (Cinnamomum verum Presl) accessions and evaluation of genetic relatedness of Cinnamon species in Sri Lanka based on trnL intron region, intergenic spacers between trnT-trnL, trnL-trnF trnH-psbA and nuclear ITS, Research Journal of Agriculture and Biological Sciences, 2009, 5(6), 1079-1088

Azad R., Senanayake G., Kumara K.L.W., Ranawaka R.A.A.K., Pushpa-Kumara D.K.N.G., Wijesinghe K.G.G., Geekiyanage S., Morphological variation within progeny and deviations from mother plant reveal the allele richness in Cinnamomum verum germ-plasm: a case study from Deiyandara, Matara collection at the early vegetative stage, Tropical Agricultural Research and Extension, 2015, 18(4), 163-167

Dassanayake M.D., Fosberg F.R., Clayton W.D. (Eds), A Revised Handbook to the Flora of Ceylon vol. IX. Amerind Publ. Co. Pvt. Ltd., New Dehli, 1995

Davis M.B., Shaw R.G., Etterson J.R., Evolutionary responses to changing climate, Ecology, 2005, 86(7), 1704-1714, DOI: 10.1890/03-0788

Department of Export Agriculture, 2013, Cinnamon, Department of Export Agriculture, Sri Lanka, http://www.exportagridept.gov.lk/ web/index.php?option=com_content\&view=article\&id=128\&lte mid=159\&lang=en (retrieved on $22^{\text {nd }}$ December, 2017)

Gamble J.S., Flora of the Presidency of Madras, Vol. 2, Botanical Survey of India, 1967
Hendry A.P., Kinnison M.T., Heino M., Day T., Smith T.B., Fitt G., et al., Evolutionary principles and their practical application, Evolutionary Applications, 2011, 4(2), 159-183, DOI: 10.1111/j.1752-4571.2010.00165.x

Hooker J., The Flora of British India, Vol. 4, London, L. Reeve \& Co, 1883

Jayaprakasha G.K., Jagan Mohan Rao L., Sakariah K.K., Volatile constituents from Cinnamomum zeylanicum fruit stalks and their antioxidant activities, Journal of agricultural and food chemistry, 2003, 51(15), 4344-4348, DOI: 10.1021/jf034169i

Joseph J., Floral biology and variation in cinnamon, PLACROSYM - IV, 1981, 431-434

Kubitzki K., Kurz H., Synchronized dichogamy and dioecy in neotropical Lauraceae, Plant systematics and evolution, 1984 , 147(3-4), 253-266, DOI: 10.1007/BF00989387

Kumarathilake D.M.H.C., Senanayake, S.G.J.N., Wijesekara, G.A.W., Wijesundara, D.S.A. Ranawaka, R.A.A.K., Extinction risk assessments at the species level: National red list status of endemic wild cinnamon species in Sri Lanka, Tropical Agricultural Research, 2010, 21(3), 247-257

Kumari H.R.S.N., Wijesinghe K.G.G., Ranawaka R.A.A.K., Study on floral behavior of selected ten cultivars of true cinnamon Cinnamomum verum (Presl.), Syn. C. zeylanicum (Blume), Proceedings of the National Symposium, 2008, 29

Mohanakumar G., Mokashi A., Narayana Swamy P., Prabhakar N., Devar K., Reddy D., et al., Studies on the floral biology of Cinnamon, Indian Cocoa, Arecanut \& Spices J, 1985, 8(4), 100-102

Nicotra A.B., Atkin O.K., Bonser S.P., Davidson A.M., Finnegan E., Mathesius U., et al., Plant phenotypic plasticity in a changing climate, Trends in plant science, 2010, 15(12), 684-692,

DOI: 10.1016/j.tplants.2010.09.008

Potvin C., Tousignant D., Evolutionary consequences of simulated global change: genetic adaptation or adaptive phenotypic plasticity, Oecologia, 1996, 108(4), 683-693, DOI: 10.1007/ BF00329043

Purseglove J., Lauraceae. In: Tropical Crops: Dicotyledons 2, 2nd ed., Purseglove J.W. ed., Longmans Green and Co. Itd. London, U.K., 1969, 187-192

Ravindran P., Nirmal Babu K., Shylaja M., Cinnamon and cassia: The genus Cinnamomum, Medicinal and Aromatic Plants- Industrial Profiles, Vol. 36, Boca Raton, London, New York, Washington, D.C. CRC press. 2004, 1-361

Reed T.E., Schindler D.E., Waples R.S., Interacting effects of phenotypic plasticity and evolution on population persistence in a changing climate, Conservation Biology, 2011, 25(1), 56-63

DOI: 10.1111/j.1523-1739.2010.01552.x

Sedgley M., Some effects of daylength and flower manipulation on the floral cycle of two cultivars of avocado (Persea americana Mill., Lauraceae), a species showing protogynous dichogamy, Journal of experimental botany, 1985, 36(5), 823-832

Volis S., Ormanbekova D., Yermekbayev K., Role of phenotypic plasticity and population differentiation in adaptation to nove environmental conditions, Ecology and evolution, 2015, 5(17), 3818-3829, DOI: 10.1002/ece3.1607

Wuu-Kuang S., Taxonomic revision of Cinnamomum (Lauraceae) in Borneo, Blumea-Biodiversity, Evolution and Biogeography of Plants, 2011, 56(3), 241-264, DOI: 10.3767/000651911X615168 